Article

\title{
Green Attributes in Young Consumers' Purchase Intentions: A Cross-Country, Cross-Product Comparative Study Using a Discrete Choice Experiment
}

\author{
Chi Thao Dinh ${ }^{1}$, Takuro Uehara ${ }^{1, *(1)}$ and Takahiro Tsuge ${ }^{2}$ \\ 1 College of Policy Science, Ritsumeikan University, Ibaraki 567-8570, Japan; ps0421ek@ed.ritsumei.ac.jp \\ 2 Graduate School of Global Environmental Studies, Sophia University, Tokyo 102-8554, Japan; \\ t-tsuge-8s2@sophia.ac.jp \\ * Correspondence: takuro@fc.ritsumei.ac.jp; Tel.: +81-72-665-2080
}

Citation: Dinh, C.T.; Uehara, T.; Tsuge, T. Green Attributes in Young Consumers' Purchase Intentions: A Cross-Country, Cross-Product Comparative Study Using a Discrete Choice Experiment. Sustainability 2021, 13, 9825. https://doi.org/ $10.3390 /$ su13179825

Academic Editor: Anat Tchetchik

Received: 5 August 2021

Accepted: 28 August 2021

Published: 1 September 2021

Publisher's Note: MDPI stays neutral with regard to jurisdictional claims in published maps and institutional affiliations.

Copyright: (c) 2021 by the authors. Licensee MDPI, Basel, Switzerland. This article is an open access article distributed under the terms and conditions of the Creative Commons Attribution (CC BY) license (https:// creativecommons.org/licenses/by/ $4.0 /)$.

\begin{abstract}
As consumption behavior is one of the key human activities destabilizing the Earth system, green consumption is expected to increase. However, although consumers often show interest in green consumption, they tend to choose non-green alternatives. Presuming that one of the reasons for their inconsistency lies in the trade-offs between green attributes and other attributes (e.g., brand, performance, and price), this study adopted a discrete choice experiment to understand how green attributes play a role in consumers' purchase decisions. To obtain a deeper understanding, the study conducted a cross-country (young Japanese $[n=370]$ and Vietnamese $[n=403]$ consumers) and product (water bottles and T-shirts) comparative analysis. The findings showed that for both products, Japanese respondents were less appreciative of green attributes in both relative and absolute terms than Vietnamese respondents. Furthermore, the marginal willingness to pay (MWTP) for a low environmental impact was the highest among the other attributes in both products for Vietnamese respondents, while this was not the case for Japanese respondents. Utilizing the findings obtained from the conditional logit models and MWTP, this study proposes several policy implications for the promotion of green purchases suitable for each country's unique situation.
\end{abstract}

Keywords: conditional logit model; discrete choice experiment; environmental Kuznets curve; green attributes; green consumption; green products; Japan; Vietnam; T-shirts; water bottles

\section{Introduction}

Since the mid-twentieth century, due to rapid economic growth, human activities have become the dominant driver of environmental changes [1]. Our heavy dependence on fossil fuels and industrialized agriculture has become so severe that it is destabilizing the Earth system on a planetary scale [2].

Consumption behavior is a key human activity that accelerates the degradation process. For the past century, the dramatic increase in the global consumption of goods and services has resulted in the severe exhaustion of natural resources, changes in global temperature, increases in pollution, and decreases in biodiversity [3]. If global consumption continues to push the Earth system beyond its safety boundaries, the consequences will be catastrophic for much of the planet [4].

People globally are starting to recognize this threat and have become more aware of their ability to prevent or reduce environmental damage by adopting environmentally friendly behaviors. As environmental issues are recognized as a priority among public opinion, green consumption has emerged as a consumption trend in the twenty-first century [5]. "Green consumption" or environmentally responsible consumption entails consumers considering the environmental impact of a product or service throughout their consumption, from purchasing to using and then disposing of it [6]. 
As green consumption increases in popularity, environmentally friendly products are becoming more common. Companies have begun to include "greenness" in their products to attract consumers who are concerned about the environment and governments have started to implement environmental policies to promote these products [7]. According to Peattie [8], a product is considered to be green when, throughout its life cycle, from production and consumption to disposal, its environmental and societal performance is significantly better than that of conventional or competitive product offerings. More specifically, Chen and Chang [9] defined "green products" as products that have less environmental impact and lower health risks, are made or partly made from recycled materials, are produced using a more energy-efficient process, or are sold in markets with less packaging. Examples include organic food, energy-efficient TVs, herbal goods, and high-efficiency washing machines. "Green purchases" generally refers to the purchase of green products [10].

However, while the majority of consumers support the idea of purchasing green products, this does not always result in purchasing intentions or behaviors [11]. Consumers often choose non-green or "browner" alternatives, and green products have gained limited success in the market $[12,13]$. This indicates the interference of other variables with consumers' perceived importance of green attributes in products. Indeed, when purchasing a product, consumers must consider an entire set of attributes. Apart from green attributes, there are other conventional attributes such as price, brand, size, performance, and accessibility. Purchase intention is determined after evaluating the importance of each attribute based on personal values [14].

As previous studies show, facing trade-offs between environmental concerns and other non-green product attributes, green products do not always have the advantage of conventional attributes (e.g., higher prices or poor accessibility) other than green features [10]. Therefore, the attribute trade-offs that consumers have to make when buying a green product may explain the failure to translate high environmental and social concerns into actual green purchase behaviors [15-17]. It is up to consumers' perceived importance of green attributes when choosing green products [18]. Consumers that prioritize environmental and social impacts emphasize green features, while those that assign higher importance to individual values usually go for functional attributes. In the latter case, customers prefer non-green products, even though they may also have environmental concerns. Most previous studies argue that green attributes are often ignored and pushed to the background when consumers make their decisions $[11,14,19]$. In other words, the consideration of individual consequences outweighs positive environmental and social attitudes [20]. Therefore, to promote green consumption, it is important to understand the influence of trade-offs involving green attributes [21].

While there have been studies on green products and consumers in general, there are a limited number of studies on young green consumers in developing countries [22,23]. Young consumers are said to be more conscious and responsible for environmental protection issues. They are also considered to be agents of change, as they are more receptive to new and innovative ideas such as green consumption $[10,24,25]$. Most studies focusing on new trends in green consumption have been conducted in developed countries, even though the market for green products in developing countries is growing, supporting the rising importance of understanding consumers in these countries. Thus, a comparative study that investigates the differences in consumption patterns between developed and developing countries would be beneficial [26]. However, few studies have investigated green purchase intentions in multiple countries [27]. Furthermore, studies comparing countries show that although the importance of considering environmental and social responsibility in consumer choices is increasing, it is not clear what value people place on these responsibilities or how things differ across markets and countries [28,29]. In addition, it could be beneficial to compare products, as consumers' green purchase intentions could differ by product, and findings could provide deeper implications for promoting green 
purchase behavior. However, few studies have compared the influence of green attributes on consumers' green purchase intentions across products in different categories [30,31].

To fill this gap, this study investigated the influence of green attributes on consumers' green purchase intentions in developed and developing countries when facing trade-offs with other attributes to elucidate the similarities and differences between countries and products. It attempted to answer the following three research questions:

RQ1. How do young consumers' green purchase intentions differ across products and countries?

RQ2. How do young consumers' heterogeneities influence their preferences for green attributes?

RQ3. How can green purchases be promoted?

In addition to exploring cross-country and cross-product differences, we investigated the influence of sociodemographic characteristics, as they are also critical factors [32,33]. Based on the findings obtained from RQ1 and RQ2, we discuss their implications for promoting green purchases. The target population included young people in Japan and Vietnam. These target countries were selected because their economies and average incomes differ. Young people were chosen as the target sample because of their importance in the advancement of an environmentally aware population. Among young consumers, university students are a group with a high education level, suggesting a better understanding of green products and environmental problems [10].

The remainder of this paper is organized as follows. Section 2 explains in detail the method used to conduct the survey and analysis. Section 3 presents the results of the survey and analysis. In Section 4, the results are discussed. Finally, Section 5 presents concluding remarks summarizing the findings of the study and explaining its limitations.

\section{Literature Review}

There has been a growing body of the literature on green products and consumers in general, including review papers $[10,22,34,35]$. Previous studies have identified factors that affect green purchase behavior [10,22,33]. For example, Joshi and Rahman [10] identified 56 factors from the literature. These previous studies cover a variety of products, including apparel [23,36-40], wine [41], cars [18,42], furniture [42], water bottles [12], food [28], and electric appliances $[12,18,43,44]$. There have been two groups of studies on green purchase behavior: psychological theories such as the theory of planned behavior $[23,29,45-47]$ and the theory of reasoned action [36], among others [39,42,43,48,49], and stated and revealed preference methods such as conjoint analysis, choice experiments, and experimental auctions $[12,18,28,38,40,44,50,51]$.

\section{Materials and Methods}

This study adopted a discrete choice experiment (DCE) approach to investigate the influence of green attributes on young consumers' green purchase intentions in Japan and Vietnam as well as to compare these intentions across product categories.

\subsection{Cases}

Green consumption is seen as a consumption trend of the twenty-first century, when environmental degradation has become a great concern for many countries including Japan and Vietnam. The situations in these two countries are both similar and different. With sustainable development in mind, the green consumption of households has become increasingly popular in Vietnam [52]. However, although Vietnamese people generally worry about the environment, they simultaneously face limited opportunities and capabilities to practice sustainable consumption [53]. A consumer study conducted in Vietnam found that young Vietnamese usually ignore green attributes when purchasing expressive products such as clothes and personal electronic devices [54]. In Japan, green consumption has also gained increasing popularity as green procurement activities have progressed, and 
bases have been found in multiple sectors. However, Japan is rather different from Vietnam. In Japan, the three main parties behind this movement are governments, companies, and non-governmental organizations, rather than individual consumers. Therefore, it is a challenge for Japan to raise awareness among general consumers and increase green consumption [55].

\subsection{Discrete Choice Experiment}

The DCE method, which is commonly used to analyze consumers' trade-offs [56], is an ideal approach to explore whether or how much consumers consider green attributes; DCEs estimate consumers' choices that vary with changes in the attributes of one alternative and elicit their degree of preference [25,57]. DCEs formulate questions or choice tasks to provide consumers with information on product preferences at the attribute level. In DCEs, a product is constructed using a set of attributes. In each question, there are several products or combinations of different product attributes for respondents to choose from [58]. Respondents jointly evaluate several important attributes and then select the alternative that they find the most attractive, such as the one that maximizes their utility in each choice task. In a real-life situation, consumers assess attributes such as the price, quality, and brand of available products and choose the product that is the most appealing to them.

\subsubsection{DCE Model Specification}

A DCE is based on the random utility maximization (RUM) model [59]. The RUM model assumes that researchers are unable to thoroughly observe all of the factors influencing people's utility, so utility is separated into two components: an observable systematic component and an unobservable random component. Given that, following the notations by Holmes et al. [56], the indirect utility $(V)$ for individual $k$ associated with chosen alternative $i$ can be formalized by the sum of the following two components:

$$
V_{i k}=v_{i k}+\varepsilon_{i k}
$$

where $v_{i k}$ is the systematic component and $\varepsilon_{i k}$ is the random component.

Respondents choose an alternative that grants them the highest utility. Therefore, an individual selects alternative $i$ when and only when

$$
v_{i k}+\varepsilon_{i k}>v_{j k}+\varepsilon_{j k} ; \forall j \in \mathrm{C}
$$

where $C$ consists of all the alternatives in the choice set.

\subsubsection{Marginal Willingness to Pay (MWTP) and Marginal Rate of Substitution}

Assume a simple linear utility function for alternative $i$, where the alternative simply represents a certain state of the world, and respondent $k$ :

$$
V_{i k}=\beta Z_{i}+\lambda\left(y_{k}-p_{i}\right)+\varepsilon_{i k}
$$

where $\beta$ is the vector of the preference parameters, except for the cost of alternative $i,\left(p_{i}\right)$. $Z$ is a vector of the attributes. $\lambda$ is the marginal utility of money.

The MWTP supposes that one conducts a choice experiment with three attributes, including the cost attribute, and the following utility function is estimated:

$$
V_{i k}=\beta_{1} z_{i 1}+\beta_{2} z_{i 2}+\lambda\left(y_{k}-p_{i}\right)+\varepsilon_{i k}
$$

$\beta_{1}, \beta_{2}, z_{i 1}$, and $z_{i 2}$ are the attributes and preference parameters for attributes 1 and 2, respectively. Then, the MWTP for an attribute (e.g., attribute 1) becomes

$$
\operatorname{MWTP} P_{1}=-\frac{\beta_{1}}{\lambda}
$$


This study applied a conditional logit model to estimate the coefficients and MWTP using R (x64 4.0.5) (https: / / www.r-project.org/ accessed on 31 August 2021), a statistical software package for DCEs [60].

\subsection{Survey Design}

\subsubsection{Selection of Products}

The first step in the choice experiment design was the selection of effective products to investigate. This selection was based on three criteria: the products chosen had to (1) have significant impacts on the environment [12], (2) be from different product categories [12,18], and (3) be gender neutral and relevant to young people. First, the selected products had to play a significant role in pushing Earth's ecosystem processes to their limit, which is a "safe operating space" for humanity without risking the stable environmental state of the Earth system [61]. Second, they had to belong to different product categories such as the convenience goods category (frequent purchases and lower prices) and the shopping goods category (less frequent purchases and higher prices). Since consumers may have different preferences (e.g., degree of trade-offs [18]) for different products, comparing a wide range of products should provide deeper implications by revealing the patterns of consumer behavior [31]. Third, the selected products could not be gender biased in the sense that one gender tended to use them more than the other. They also had to be relatively common items in daily life among young people, especially university students, who were the target population of the study.

This study selected T-shirts and water bottles, which satisfied these criteria. T-shirt production and consumption have great environmental impacts involving biodiversity loss and biogeochemical flow processes, both of which have a high risk of approaching their boundaries [4]. Chemicals are the main components of conventional clothes, even clothes made of " $100 \%$ natural" fiber. Moreover, in most countries that produce clothes, untreated contaminated wastewater from textile factories is poured directly into rivers. Synthetic fibers such as polyester are plastic fibers that are non-biodegradable and take up to 200 years to decompose [62]. Concerning green alternatives (green clothes made of organic or recycled fabric), attribute trade-offs require intense consideration because green clothing is much more expensive, cannot keep up with trends, and cannot include specific features such as heat technology [63].

\subsubsection{Selection of Attributes and Attribute Levels}

Previous studies have suggested that selected attributes should be viewed as endpoints that directly result in consumer utility functions [64]; in other words, selected attributes and their levels should be directly connected to consumers' preferences for goods. Furthermore, attributes should be demand-relevant (what consumers deem valuable), measurable (can be translated into quantity), interpretable (easy to understand for non-scientist respondents), comprehensive (including all the key attributes), and policy-relevant (what decision-makers can influence) [65].

First, relevant attributes were shortlisted based on previous studies on green consumption intentions and behaviors with reference to the abovementioned criteria: brand, performance, availability, price, and environmental impact $[10,14,18,33,66]$. To finalize the attributes and their levels, three focus groups were conducted with Japanese college students on 25 February 2021, Vietnamese environmentally conscious consumers on February 26, and Vietnamese college students on March 4 and 5. Five attributes with different levels were selected for T-shirts and four were selected for water bottles (Table 1). The same levels, except for prices, were used for both countries to make them comparable.

- $\quad$ Brand: The popularity of a product influences consumers' purchase intentions. Familiar brands are believed to be of better quality and are therefore more reliable and valuable [14].

- Quality/function: Previous studies have shown that perceived product quality and function significantly influence consumers' purchase intentions [10]. The performance 
of a product directly enters the utility function of consumers and, therefore, is a major determinant of green purchase intentions [10]. Given this notion, different available functions capturing quality/performance were assigned to each product as options for performance for T-shirts and water bottles.

- Accessibility: Time taken, accessibility, and convenience significantly affect consumers' purchase intentions $[33,67]$. Similarly, whether a green product is readily available directly changes green purchase intentions [33].

- Price: The results of previous research on whether consumers are willing to pay premium prices for green products have shown that their purchase intentions are noticeably sensitive to changes in price [10]. The price ranges for each product reflected the current market prices in Japan and Vietnam.

- Environmental impact: Environmental impact levels were adopted to investigate the sensitivity of consumer preferences to the green features of a product. The environmental impact of a selected product was presented to consumers as a rating verified by independent experts based on the product's contribution to (1) global warming, (2) water pollution, and (3) air pollution throughout its life cycle [68].

Table 1. Attributes and their levels for t-shirts and water bottles.

\begin{tabular}{|c|c|c|}
\hline \multicolumn{3}{|c|}{ T-Shirts } \\
\hline \multirow{2}{*}{ Attribute } & \multicolumn{2}{|c|}{ Levels } \\
\hline & Vietnam & Japan \\
\hline \multirow{2}{*}{ Brand } & Brand (e.g., Uniqlo, Canifa, Hanosimex) & Brand (e.g., Uniqlo, GU, GAP) \\
\hline & No brand & No brand \\
\hline \multirow[b]{2}{*}{ Quality } & Premium cotton & Premium cotton \\
\hline & Regular cotton & Regular cotton \\
\hline \multirow{4}{*}{ Accessibility } & Available 60 min away & Available 60 min away \\
\hline & Available 30 min away & Available 30 min away \\
\hline & Available 10 min away & Available 10 min away \\
\hline & 100 & 1000 \\
\hline \multirow{2}{*}{ Price (tVND/JPY) } & 200 & 2000 \\
\hline & 500 & 5000 \\
\hline & 800 & 8000 \\
\hline \multirow{3}{*}{ Environmental impact } & Low & Low \\
\hline & Medium & Medium \\
\hline & High & High \\
\hline \multicolumn{3}{|c|}{ Water bottles } \\
\hline \multirow{2}{*}{ Attribute } & \multicolumn{2}{|c|}{ Levels } \\
\hline & Vietnam & Japan \\
\hline \multirow{5}{*}{ Thermal preservation } & Brand (e.g., Lock\&Lock, Lavie) & Brand (e.g., Thermos, Suntory) \\
\hline & No brand & No brand \\
\hline & Yes & Yes \\
\hline & No & No \\
\hline & 50 & 500 \\
\hline \multirow{4}{*}{ Price (tVND/JPY) } & 150 & 1000 \\
\hline & 300 & 3000 \\
\hline & 500 & 6000 \\
\hline & Low & Low \\
\hline \multirow[t]{2}{*}{ Environmental impact } & Medium & Medium \\
\hline & High & High \\
\hline
\end{tabular}

\subsubsection{Questionnaire Design}

After choosing the attributes and their levels, the next step was to build a set of possible alternatives with different attribute levels and then pair these profiles to make choice sets. The complete factorial design that incorporated every possible combination of all attributes is shown in Table 1, containing 48 possible choice combinations for water 
bottles and 72 for T-shirts. To narrow this to a manageable number, a subset of these combinations was used.

For this purpose, a D-efficient design was constructed using Ngene version 1.2.1. A pilot study containing 20 choice questions ( 10 for each product) was conducted with 22 Japanese and 21 Vietnamese respondents to obtain prior values [69]. These prior values were then used to design the questions for the official survey. As the analysis of the pilot study was not pooled, the choice sets for Japanese and Vietnamese respondents were different. For each country, 16 choice sets with two product options (i.e., two products with different characteristics) and a no-choice option were generated for each product. As 16 choice sets for each product were too many for an individual to evaluate, they were randomly divided into two versions, so that each respondent was provided with eight choice sets for each product. Figure 1 presents an example of the choice sets used in the questionnaire.

\begin{tabular}{|c|c|c|}
\hline & Shirt 1 & Shirt 2 \\
\hline Brand & Brand (e.g., Uniqlo, GU, GAP) & No brand \\
\hline Quality & Regular cotton & Premium cotton \\
\hline Accessibility & Available 30 min away & Available 10 min away \\
\hline \multirow{2}{*}{ Environmental impact } & & \\
\hline & & \\
\hline Price (JPY) & Medium & Low \\
\hline
\end{tabular}

\author{
I will choose to purchase: \\ - Shirt 1 \\ - Shirt 2 \\ - None
}

Figure 1. Example of a choice set used in the questionnaire. Green, yellow, and red indicate low, medium, and high environmental impact accordingly.

The questionnaire comprised three main sections. The first section was the choice experiment with a description of the selected attributes and 16 choice sets (eight for each product). The second section asked consumers about their environmental knowledge, green purchase attitudes, and perceived personal environmental values. Finally, the last section of the questionnaire asked respondents about their individual demographic and socioeconomic characteristics. In addition to gender, we asked respondents about their disposable income and environmental concerns. While a previous study showed mixed results (i.e., its significance depended on the model specification) [25], income remains a key element of stated preference methods [70]. Each scale included three items drawn from previous studies $[18,45,54,71-73]$. The reliability of each scale was tested using Cronbach's $\alpha$.

This study also conducted a follow-up survey of the same Japanese respondents based on the findings obtained from the questionnaire. A structured questionnaire was used to explore the reasons for these findings. A follow-up survey was not conducted with Vietnamese respondents, as we could not reach them.

\title{
3.4. Participants
}

The questionnaire was administered to young people from 17 to 25 years old in Japan and Vietnam using online questionnaire platforms from 6 to 20 May 2021. The questionnaire for Japanese respondents was conducted at the College of Policy Science at a university in Japan. The number of valid answers collected from Japan was 370. A total of 403 valid answers were collected from Vietnam from two sources: one was administered to 
students in four classes, 180 students in total, in the Faculty of Education at a university in Vietnam and the rest of the Vietnamese respondents were collected through snowball sampling using an online survey and social media platforms, some of which were master's students or new graduates. The respondents whose answers were used for the analyses in this study provided informed consent. The data in Excel are available online as a supplementary material.

\section{Results}

\subsection{Consumers' Characteristics}

A total of 773 valid questionnaires were collected: 370 in Japan and 403 in Vietnam. Table 2 shows the basic sociodemographic characteristics of the participants. Because of limited access to young consumers, gender ratios deviated from the population to some extent. Although this study chose products that were not gender biased, there is still the possibility of sample selection bias. While the sex ratio for Japanese aged 18-21 is 1.06 [74], the ratio in the Japanese sample was 1.48. The sex ratio for Vietnamese aged 18-25 is 1.04 [75] and the ratio in the Vietnamese sample was 0.49. The disposable income for Japanese consumers may be similar to that of the national survey, which revealed that the monthly disposable income for college students at private universities is JPY 54,975 [76]. There are no national statistics on the average disposable income of Vietnamese college students.

Table 2. Sociodemographic characteristics of the sample.

\begin{tabular}{|c|c|c|c|c|}
\hline & $\begin{array}{l}\text { Japan } \\
(n=370)\end{array}$ & & $\begin{array}{l}\text { Vietnam } \\
(n=403)\end{array}$ & \\
\hline \multirow{2}{*}{ Gender } & Female & $40.3 \%$ & Female & $67.0 \%$ \\
\hline & Male & $59.7 \%$ & Male & $33.0 \%$ \\
\hline \multirow{5}{*}{$\begin{array}{l}\text { Disposable income } \\
\text { (JPY/VND) }\end{array}$} & Below 50,000 & $60.3 \%$ & Below 2,000,000 & $46.6 \%$ \\
\hline & 50,000-below 100,000 & $34.1 \%$ & 2,000,000-below 5,000,000 & $31.3 \%$ \\
\hline & 100,000 -below 150,000 & $4.3 \%$ & $5,000,000$-below $7,000,000$ & $9.7 \%$ \\
\hline & Above 150,000 & $1.4 \%$ & $7,000,000$-below $10,000,000$ & $5.5 \%$ \\
\hline & & & Above $10,000,000$ & $6.9 \%$ \\
\hline
\end{tabular}

Table 3 shows consumers' environmental knowledge, attitude, and values. Cronbach's $\alpha$ indicated that all of them were reliable scales (i.e., $\alpha>0.7$ ) [77]. Comparing Japanese with Vietnamese respondents, Vietnamese respondents scored higher in all aspects of environmental concern; a t-test revealed that their mean values were statistically significantly different $(p$-values all $<0.001)$.

\subsection{Model Estimates}

Tables 4 and 5 show the conditional logit models for water bottles by country, with and without interaction terms. Tables 6 and 7 show the conditional logit models for T-shirts by country, with and without interaction terms. Tables 5 and 7 add the heterogeneity of the respondents' preferences based on their profiles (i.e., income and gender) to the models in Tables 4 and 6, respectively. Table 8 shows the MWTP for both products and countries. To make them comparable across countries, they were converted into U.S. dollars (USD) using the online service by the Money Converter (https://themoneyconverter.com/). The exchange rate at the time of access (30 July 2021) was VND $1000=$ USD 0.04 and JPY 1 = USD 0.01 .

For the Vietnamese respondents, all the choice attributes for both products were statistically significant at the $1 \%$ level (Tables 4 and 6 ). In Japan, most of the choice attributes were statistically significant at the $1 \%$ level, except for premium cotton for T-shirts (Tables 4 and 6). 
Table 3. Environmental knowledge, attitude, and values.

\begin{tabular}{|c|c|c|c|c|}
\hline & \multicolumn{2}{|c|}{ Japan } & \multicolumn{2}{|c|}{ Vietnam } \\
\hline & Mean & Cronbach's $\alpha$ & Mean & Cronbach's $\alpha$ \\
\hline Environmental Knowledge & 2.89 & 0.83 & 3.72 & 0.86 \\
\hline I am knowledgeable about environmental issues & 3.18 & & 3.74 & \\
\hline I am knowledgeable about green products & 2.79 & & 3.58 & \\
\hline $\begin{array}{l}\text { I am knowledgeable about the environmental } \\
\text { impacts of green products }\end{array}$ & 2.71 & & 3.85 & \\
\hline Green Purchase Attitude & 2.8 & 0.71 & 3.79 & 0.87 \\
\hline I enjoy purchasing green products & 2.64 & & 3.87 & \\
\hline $\begin{array}{l}\text { Green features are a very useful piece of information } \\
\text { that I consider when I buy something }\end{array}$ & 3.30 & & 3.98 & \\
\hline $\begin{array}{l}\text { I look for green alternatives when I want to } \\
\text { buy something }\end{array}$ & 2.47 & & 3.52 & \\
\hline Personal Values & 2.96 & 0.72 & 3.89 & 0.82 \\
\hline $\begin{array}{l}\text { I feel personally obliged to buy green products to } \\
\text { protect the environment }\end{array}$ & 3.10 & & 3.96 & \\
\hline $\begin{array}{l}\text { I am deeply concerned about the environmental } \\
\text { impact of my product consumption }\end{array}$ & 2.79 & & 3.83 & \\
\hline $\begin{array}{l}\text { I feel guilty when I purchase products that harm } \\
\text { the environment }\end{array}$ & 2.98 & & 3.87 & \\
\hline
\end{tabular}

Table 4. Conditional logit models for water bottles including the choice attributes only.

\begin{tabular}{|c|c|c|c|c|}
\hline & \multicolumn{2}{|c|}{ Japan } & \multicolumn{2}{|l|}{ Vietnam } \\
\hline & Coef. est. & Sd. Error & Coef. est. & Sd. Error \\
\hline \multicolumn{5}{|l|}{ Choice Attributes } \\
\hline Brand & 0.12647 & $0.02827 * * *$ & 0.32793 & $0.02691^{* * *}$ \\
\hline No brand & -0.12647 & & -0.32793 & \\
\hline Thermal preservation_Yes & 0.51775 & $0.04825 * * *$ & 0.15875 & $0.02675^{* * *}$ \\
\hline Thermal preservation_No & -0.51775 & & -0.15875 & \\
\hline Environmental Impact_Low & 0.11643 & $0.0415^{* * *}$ & 0.40959 & $0.04507^{* * *}$ \\
\hline Environmental Impact_Medium & 0.30166 & $0.03293 * * *$ & 0.20366 & $0.03259 * * *$ \\
\hline Environmental Impact_High & -0.41809 & & -0.61325 & \\
\hline Price & -0.31947 & $0.02481 * * *$ & -0.19448 & $0.01569^{* * *}$ \\
\hline \multicolumn{5}{|l|}{ Model summary statistics } \\
\hline Log likelihood & -3001.711 & & -3541.926 & \\
\hline Adjusted rho-squared & 0.0724027 & & 0.0655693 & \\
\hline AIC & 6065.504 & & 6619.369 & \\
\hline $\mathrm{BIC}$ & 6101.494 & & 6655.839 & \\
\hline Number of observations & 8880 & & 9672 & \\
\hline Number of respondents & 370 & & 403 & \\
\hline
\end{tabular}

*** $p<0.01 ; * * p<0.05 ; * p<0.10$.

All the models except for the model for T-shirts of the Japanese sample were linear in terms of the choice attributes and interaction terms. As "Accessibility" alone was not statistically significant, we added "Accessibility^2," the quadratic term of "Accessibility." The reason for this functional form could be explained by our choice of attribute levels in the survey, while the attribute levels were set at 10,30, and $60 \mathrm{~min}$, and the follow-up survey with Japanese respondents $(n=382)$ indicated that most of them usually went shopping 30 min away (mean $=30.97$, median and mode $=30$ ). Therefore, their current shopping behavior could influence their preferences, or $30 \mathrm{~min}$ away could be a reflection of their preferences. 
Table 5. Conditional logit models for water bottles including the interaction terms.

\begin{tabular}{|c|c|c|c|c|}
\hline & \multicolumn{2}{|c|}{ Japan } & \multicolumn{2}{|l|}{ Vietnam } \\
\hline & Coef. est. & Sd. Error & Coef. est. & Sd. Error \\
\hline \multicolumn{4}{|l|}{ Choice Attributes } & $0.063998 * * *$ \\
\hline Brand & 0.12304 & $0.02841 * * *$ & 0.329737 & $0.026964^{* * *}$ \\
\hline No brand & -0.12304 & & -0.329737 & \\
\hline Thermal preservation_Yes & 0.51448 & $0.04842 * * *$ & 0.158751 & $0.02675^{* * *}$ \\
\hline Thermal preservation_No & -0.51448 & & -0.158751 & \\
\hline Environmental Impact_Low & 0.16467 & 0.11679 & 0.45435 & $0.084214^{* * *}$ \\
\hline Environmental Impact_Medium & 0.37836 & $0.10658^{* * *}$ & 0.266158 & $0.073844^{* * *}$ \\
\hline Environmental Impact_High & -0.54303 & & -0.720508 & \\
\hline Price & -0.31593 & $0.02488^{* * *}$ & -0.195173 & $0.0157^{* * *}$ \\
\hline \multicolumn{5}{|l|}{ Interaction terms } \\
\hline Environmental Impact_Low * Income & -0.01502 & 0.01696 & 0.004676 & 0.013657 \\
\hline $\begin{array}{c}\text { Environmental Impact_Medium * } \\
\text { Income }\end{array}$ & -0.02137 & 0.0157 & -0.005714 & 0.012752 \\
\hline Environmental Impact_Low ${ }^{*}$ Gender & 0.10365 & 0.07028 & -0.09127 & 0.07066 \\
\hline $\begin{array}{c}\text { Environmental Impact_Medium * } \\
\text { Gender }\end{array}$ & 0.15899 & $0.06629 * *$ & -0.06037 & 0.0659 \\
\hline \multicolumn{5}{|l|}{ Model summary statistics } \\
\hline Log likelihood & -3001.711 & & -3301.58 & \\
\hline Adjusted rho-squared & 0.074 & & 0.065 & \\
\hline AIC & 6023.423 & & 6623.16 & \\
\hline $\mathrm{BIC}$ & 6083.352 & & 6683.944 & \\
\hline Number of observations & 8880 & & 9672 & \\
\hline Number of respondents & 370 & & 403 & \\
\hline
\end{tabular}

${ }^{* * *} p<0.01 ;{ }^{* *} p<0.05 ;{ }^{*} p<0.10$.

Table 6. Conditional logit models for T-shirts including choice attributes only.

\begin{tabular}{|c|c|c|c|c|}
\hline & \multicolumn{2}{|c|}{ Japan } & \multicolumn{2}{|l|}{ Vietnam } \\
\hline & Coef. est. & Sd. Error & Coef. est. & Sd. Error \\
\hline Alternative specific constant & -1.514368 & $0.16685^{* * *}$ & -1.92821 & $0.10127^{* * *}$ \\
\hline \multicolumn{5}{|l|}{ Choice Attributes } \\
\hline Brand & 0.295758 & $0.022731^{* * *}$ & 0.33791 & $0.02196^{* * *}$ \\
\hline No brand & -0.295758 & & -0.33791 & \\
\hline Quality_Premium cotton & 0.009065 & 0.027333 & 0.22044 & $0.02876^{* * *}$ \\
\hline Quality_Regular cotton & -0.009065 & & -0.22044 & \\
\hline Accessibility & 0.348977 & $0.095614^{* * *}$ & -0.12068 & $0.01364^{* * *}$ \\
\hline Accessibility ${ }^{\wedge} 2$ & -0.047667 & $0.013353^{* * *}$ & & \\
\hline Environmental Impact_Low & 0.06357 & $0.036497^{*}$ & 0.52366 & $0.03792 * * *$ \\
\hline Environmental Impact_Medium & 0.155646 & $0.037294^{* * *}$ & 0.13043 & $0.03226^{* * *}$ \\
\hline Environmental Impact_High & -0.219216 & & -0.65409 & \\
\hline Price & -0.287698 & $0.016384^{* * *}$ & -0.26192 & $0.01391^{* * *}$ \\
\hline \multicolumn{5}{|l|}{ Model summary statistics } \\
\hline Log likelihood & -2708.472 & & -3119.742 & \\
\hline Adjusted rho-squared & 0.1646488 & & 0.1172199 & \\
\hline AIC & 5432.944 & & 6253.484 & \\
\hline $\mathrm{BIC}$ & 5480.888 & & 6296.032 & \\
\hline Number of observations & 8880 & & 9672 & \\
\hline Number of respondents & 370 & & 403 & \\
\hline
\end{tabular}


Table 7. Conditional logit models for T-shirts including interaction terms.

\begin{tabular}{|c|c|c|c|c|}
\hline & \multicolumn{2}{|c|}{ Japan } & \multicolumn{2}{|l|}{ Vietnam } \\
\hline & Coef. est. & Sd. Error & Coef. est. & Sd. Error \\
\hline \multicolumn{5}{|l|}{ Choice Attributes } \\
\hline Brand & 0.297470 & $0.022788^{* * *}$ & 0.337102 & $0.02204^{* * *}$ \\
\hline No brand & -0.297470 & & -0.337102 & \\
\hline Quality_Premium cotton & 0.008158 & 0.027389 & 0.22238 & $0.028786^{* * *}$ \\
\hline Quality_Regular cotton & -0.008158 & & -0.22238 & \\
\hline Accessibility & 0.349892 & $0.095670 * * *$ & -0.121089 & $0.01365^{* * *}$ \\
\hline Accessibility^2 & -0.047724 & $0.013359 * * *$ & & \\
\hline Environmental Impact_Low & -0.174092 & 0.114185 & 0.594787 & $0.078872 * * *$ \\
\hline Environmental Impact_Medium & 0.267333 & $0.121714^{* *}$ & 0.057333 & 0.075883 \\
\hline Environmental Impact_High & -0.093241 & & -0.65212 & \\
\hline Price & -0.287476 & $0.016393 * * *$ & -0.262823 & $0.013923 * * *$ \\
\hline \multicolumn{5}{|l|}{ Interaction terms } \\
\hline Environmental Impact_Low * Income & 0.036653 & $0.016726^{* *}$ & 0.004815 & 0.013386 \\
\hline Environmental Impact_Medium * Income & -0.021341 & 0.017896 & 0.012512 & 0.013218 \\
\hline Environmental Impact_Low * Gender & 0.016356 & 0.070441 & -0.13315 & $0.068776 *$ \\
\hline Environmental Impact_Medium * Gender & 0.057338 & 0.075224 & 0.038711 & 0.06834 \\
\hline \multicolumn{5}{|l|}{ Model summary statistics } \\
\hline Log likelihood & -2705.483 & & -3117.132 & \\
\hline Adjusted rho-squared & 0.1643379 & & 0.1168274 & \\
\hline AIC & 5434.967 & & 6256.264 & \\
\hline $\mathrm{BIC}$ & 5506.882 & & 6323.126 & \\
\hline Number of observations & 8880 & & 9672 & \\
\hline Number of respondents & 370 & & 403 & \\
\hline
\end{tabular}

Table 8. MWTP for water bottles and T-shirts by country in USD.

\begin{tabular}{ccccc}
\hline & Water Bottles & \multicolumn{3}{c}{ T-Shirts } \\
\cline { 2 - 5 } & Japan & Vietnam & Japan & Vietnam \\
\hline Brand & 7.22 & 14.65 & 18.75 & 11.21 \\
Thermal preservation & 29.56 & 7.09 & - & - \\
Quality_Premium cotton & - & - & 0.57 & 7.31 \\
Accessibility & - & - & 11.07 & -2.01 \\
Accessibility² & - & - & -1.52 & - \\
Environmental impact_Low & 15.26 & 22.85 & 8.96 & 19.53 \\
Environmental & 20.54 & 18.25 & 11.88 & 13.01 \\
impact_Medium & & & & \\
\hline
\end{tabular}

The interaction terms in Tables 5 and 7 show how the heterogeneity of respondents' preferences based on their sociodemographic characteristics. Only the interaction term for medium environmental impact and gender for water bottles for Japanese respondents was statistically significant (Table 5). As for T-shirts, the interactions between low environmental impact and income for Japanese respondents and between low environmental impact and gender for Vietnamese consumers were statistically significant (Table 7).

The MWTP in Table 8 was estimated based on the corresponding conditional logit models, including the choice attributes only (Tables 4 and 6).

\section{Discussion}

\subsection{Differences in Consumers' Green Purchase Intentions across Countries and Products}

The comparison of the MWTP for Environmental Impact_Low and High in Table 8 shows a stark contrast between Japanese and Vietnamese respondents. While Vietnamese respondents valued low environmental impact more than medium for both water bottles (USD 22.85 and USD 18.25) and T-shirts (USD 19.53 and USD 13.01), Japanese respondents 
valued low environmental impact less than medium for both products (USD 15.26 and USD 20.54 for water bottles; USD 8.96 and USD 11.88 for T-shirts). This indicates that green attributes (i.e., Environmental Impact_Low) contribute less to Japanese respondents' purchase intentions. There are two possible reasons for this finding. First, it could be that Vietnamese consumers are more concerned about their consumption than Japanese consumers. Their environmental knowledge, attitudes, and values were higher than those of the Japanese (Table 3). This is in accordance with the environmental Kuznets curve [78]; the improvement of environmental quality will be tapered at some point, as the marginal utility of additional improvement in environmental quality is declining as the economy grows. This is also supported by previous studies indicating that sustainable consumption trends influence consumers in emerging countries more than in developed ones $[79,80]$. This may be because developing countries, including Vietnam, are more exposed to environmental pollution and environmental damage from climate change [80-82]. Second, it could be that Japanese consumers take environmentally friendly products for granted. This was confirmed by the results of the follow-up survey, where $37 \%$ and $40 \%$ of Japanese respondents thought that water bottles and T-shirts available in Japan are already environmentally friendly, respectively (only 18\% and 19\% chose "disagree" or "strongly disagree," respectively). Since Japanese respondents are familiar with environmental regulations and eco-friendly practices in Japan, they thought that the average environmental impact is sufficiently environmentally friendly and that there is no need to pursue further environmental friendliness. As we could not conduct a follow-up survey of Vietnamese respondents, we cannot make a comparison, and no official data state whether products in Vietnam are not environmentally friendly. However, there is evidence to prove that the production practices of enterprises in Vietnam are not sustainable compared with those of other countries $[83,84]$. Moreover, the overall environmental performance index of Japan is also higher than that of Vietnam [85]. Therefore, Japanese people may be less sensitive to improvements in environmental impacts.

The comparison of the MWTP for environmental impacts in relation to that for the other attributes also showed a stark contrast between Japanese and Vietnamese respondents. As the MWTP in Table 8 shows, among all the attributes, Vietnamese respondents were willing to pay the most for low environmental impact (USD 22.85 for water bottles and USD 19.53 for T-shirts), followed by medium environmental impact for both products. By contrast, green attributes were not a priority for either product for Japanese respondents. Thermal preservation (USD 29.56) and brand (USD 18.75) were the most important for Japanese respondents for water bottles and T-shirts. Vietnamese respondents' preferences were in line with the results of a survey by Nielsen Vietnam in 2017, where $80 \%$ of the interviewed Vietnamese reported that they would pay more for environmentally friendly products [86].

As for the cross-product comparison, both Japanese and Vietnamese consumers valued the green attributes of water bottles more than those of T-shirts. As they were different types of products (e.g., their duration of use and utility), further investigation is needed to understand what this difference means. Another interesting point is that Vietnamese respondents with lower purchasing power were more willing to pay for green attributes. In comparison with consumers' average monthly disposable income, the estimated MWTP for low environmental impact accounted for $0.4 \%$ (T-shirts) to $0.6 \%$ (water bottles) of respondents' average monthly disposable income in the Japanese sample and 5.3\% (T-shirts) to $5.6 \%$ (water bottles) in the Vietnamese sample. This means that Japanese respondents were willing to pay less for green attributes than Vietnamese respondents.

\subsection{Heterogeneities of Green Purchase Intentions Due to Respondents' Profiles}

The interaction terms in Tables 5 and 7 show how respondents' preferences differed according to their sociodemographic characteristics (i.e., gender and income). Interestingly, contrary to studies' claim that a gender gap exists (i.e., women tend to prefer green products more than men) [87-89], this study showed mixed results. The influence of environmental 
impact on purchase intentions varied according to gender in the water bottle results for Japanese respondents and in the T-shirt results for Vietnamese respondents. Interestingly, while Japanese female respondents valued a medium (average) environmental impact of water bottles more than male respondents, contrary to the literature, Vietnamese male respondents valued a lower environmental impact of T-shirts than female respondents. There are various explanations for this gender gap. For example, traditional gender socialization is often used to explain this bias, with researchers stating that cultural norms and women's traditional role as caregivers have encouraged women to be cooperative and compassionate, as well as forming a nurturing nature that eventually leads to higher concern for maintaining the surrounding environment [90]. Another explanation is ascribed to the green feminine stereotype; both men and women tend to have the stereotype that green consumers are more feminine, which makes men avoid adopting green behaviors to maintain their gender identity [91]. However, due to the paucity of the literature explaining why men sometimes prefer green products more than women, it is difficult to address this finding. However, as the gender gap is explained by the context (e.g., socialization and stereotypes), Vietnamese society may be unique, and the validation of this notion awaits future study.

Overall, respondents' preferences did not differ by income, except for the low environmental impact of Japanese respondents. Vietnamese respondents had low environmental impact, irrespective of their income level. While income is often a definitive factor for explaining adults' willingness to pay for environmental protection [87-89], a recent study targeting young people receiving an allowance showed no statistical significance [25]. As most respondents in both countries were full-time students, they mostly depended on an allowance provided by, for example, their parents. In our study, it is interesting that while low environmental impact was not significant for Japanese consumers overall, the interaction term indicated that it varied according to income level: the higher income, the lower is environmental impact. Although this could not be validated, respondents with higher income may be more sensitive to or aware of environmental issues as they work part-time and become more concerned about social issues, including environmental issues. Learning about society is one of the reasons Japanese university students work part-time [92].

\subsection{Implications for Promoting Green Purchases}

As Japanese and Vietnamese respondents valued environmental impacts to different degrees, different implications or measures for promoting green purchases are expected. While Vietnamese respondents valued low levels of environmental impact, Japanese respondents valued medium (average) environmental impact, or the status quo, more than a better (i.e., lower) environmental impact. This indicates that Japanese consumers are less sensitive to environmental quality than Vietnamese consumers. Furthermore, low and medium environmental impacts were not as important as the other attributes of water bottles and T-shirts. This is a concern, as previous studies have shown that we are about to cross the threshold of Earth's safe operating space [93]. This indicates that Japan needs to make further efforts to protect the environment regardless of the extent to which Japanese consumers are satisfied with the current situation.

Therefore, it is critical to implement policy measures to help Japanese consumers become more aware that environmental issues are still serious and encourage them to adopt green behaviors. To do so, for example, environmental education has been proven to be effective [94]. A mass public information campaign about ecosystem services, environmental issues, and environmental quality could significantly improve people's environmental knowledge and values, in turn helping them make more informed choices to protect the environment [95]. Another way to promote sustainable behavior is to apply green nudges to people's daily activities. For example, the plastic bag charge has been successful in encouraging citizens to reuse shopping bags in Japan as well as in raising Japanese consumers' awareness of the issue of plastic waste [96]. Thus, similar nudges such as charges for plastic 
cups, plastic straws, and other plastic cutlery in coffee shops, convenience stores, and restaurants could be applied. These nudges could spur other green practices in consumers, as one environmental behavior can lead to others [97].

Although green attributes were not as important for Japanese consumers as were the other attributes of water bottles and T-shirts, as indicated by the MWTP in Table 8, this can be utilized to promote green products. For example, brand was valued greatly in Japan, especially for T-shirts (USD 18.75 for Brand but USD 8.96 for Environmental Impact_Low in Table 8). This demonstrates that it is important to involve companies with famous brand images to produce and sell environmentally friendly products. To promote green purchases, the government could work toward a voluntary agreement with these big brands instead of all companies designing environmentally friendly products. Voluntary agreements are one of the key policy measures for conserving the Earth system [98].

Vietnamese respondents prioritized the environmental impact of products and were willing to purchase green products. This suggests that in contrast to the lack of environmental awareness as a key concern in Japan, for Vietnam, the slow pace of sustainable consumption may be due to deficiencies in product supply. Since market demand for environmentally friendly products seems to be high, as indicated by our findings, an increase in the availability or production of these products will increase green consumption practices. Indeed, brands and companies that commit to selling green and clean products such as Unilever Vietnam, Dien Quang Lamp Joint Stock Company, and Ecopark have a growth rate four times higher than that of other enterprises in the same industry [99]. However, the number of products considered to be green in Vietnam is small, making opportunities for Vietnamese consumers to practice sustainable consumption limited despite their high environmental awareness. Green products and services account for only approximately one-10th of GDP [100]. From 2009 to 2014, only four companies applied for and were certified with the Vietnam Green Label (VGL), the eco-label awarded to products that meet the government's criteria for eco-friendly products [98]. Therefore, the next step for the government should be to encourage companies to improve their production practices to meet the VGL criteria for eco-friendly products and popularize the existence of this label to companies and consumers [101]. The government can eventually certify the mandatory VGL environmental criteria in all production practices to reduce unsustainable products [93]. The government can also use subsidies to promote the creation of green products, as subsidies have been proven to be a highly effective policy instrument to increase not only green product innovations but also green innovations in production processes [102]. Moreover, the results indicated that green products can be more attractive to Vietnamese consumers by utilizing brand, function, or quality attributes. This means that green purchase intentions significantly increase when products have no disadvantages in terms of quality or performance compared with other conventional products on the market. This calls for measures to improve product innovation in firms. Similar to Japan, brands are also valued by Vietnamese consumers. Thus, a voluntary agreement between the government and big brands to produce and sell green products should also be applied in the country.

\section{Conclusions}

As environmental issues become more distressing, green consumption has emerged as a new consumption trend in many countries worldwide [22]. However, despite rising support for environmentally friendly products, consumers often opt for fewer green alternatives. This can be explained by the attribute trade-offs that consumers have to make when choosing a product. Therefore, knowing consumers' preferences can help promote the consumption of green products. This study applied a DCE to investigate the influence of green attributes on young consumers' green purchase intentions through comparisons by country (i.e., developed vs. developing) and product. Through cross-country and cross-product comparisons, this study provided a deeper understanding of the influence of greenness and its trade-offs with other key attributes to elicit policy implications for 
encouraging young consumers to choose green products. Young consumers are key players in the Earth's future.

The findings showed a stark contrast between Japanese and Vietnamese respondents regarding their preferences for green attributes. Notably, Japanese respondents were less appreciative of the green attributes of both products than Vietnamese respondents, even though Japanese respondents' income levels were higher than those of Vietnamese respondents. Furthermore, as the MWTP indicated, not only low environmental impact but also even medium (average) or status quo environmental quality was not a priority among the other attributes for Japanese consumers, whereas better environmental quality was a priority for Vietnamese respondents (i.e., the highest MWTP for low environmental impact). Provided that consumption behavior is one of the key driving forces destabilizing the Earth system, the low preference for environmental quality by Japanese should be of particular concern. The conditional logit models demonstrated two possible solutions. One is to raise environmental awareness among Japanese consumers through public policy, including environmental education and information campaigns [94,95]. Another possibility is to sell products by taking advantage of other preferred attributes (e.g., sold by a well-known brand and with better performance) instead of advertising the "greenness." Although it is up to companies to decide what and how to sell their products, the government can encourage them to sell green products by informing them of what trade-offs lie in green products and how they can sell greener products and ask for voluntary agreements to produce green products. In contrast to Japan, Vietnamese respondents valued low environmental impact greatly in both products and were willing to pay more for green products. This indicates that it is crucial to improve the availability of green products in Vietnam. There may be strong demand, but a lack of supply. To do so, the government can implement stricter environmental regulations in production and subsidize green product innovations and green production process innovations. Moreover, as brands are also valued by Vietnamese respondents, the Vietnamese government can cooperate with famous brands to bring more green products to the market.

There are at least two limitations of this study that create possibilities for future studies. First, this study did not aim to fill the gap between intention and behavior [33]. Further studies are needed to fill this gap $[33,103,104]$. Second, this study intended to elicit policy implications for choosing green products and not reducing total consumption. However, as previous studies on plastic pollutants claim, reducing consumption is essential to protect the environment $[105,106]$. Therefore, more studies are needed to investigate how people choose products that can be used longer and how people use products for longer (e.g., object attachment [107] and product attachment [108]).

Supplementary Materials: The data for the paper are available online at https: / www.mdpi.com/ article/10.3390/su13179825/s1.

Author Contributions: Conceptualization, C.T.D.; Methodology, C.T.D., T.U. and T.T.; Software, C.T.D. and T.T.; Validation, T.T.; Formal Analysis, C.T.D.; Investigation, C.T.D.; Resources, C.T.D. and T.U.; Data Curation, C.T.D. and T.U.; Writing-Original Draft Preparation, C.T.D.; Writing—Review \& Editing, C.T.D., T.U. and T.T.; Visualization, C.T.D.; Supervision, T.U. and T.T.; Project Administration, C.T.D.; Funding Acquisition, T.U. All authors have read and agreed to the published version of the manuscript.

Funding: This research was funded by Ritsumeikan University.

Institutional Review Board Statement: Ethical review and approval were waived for this study. It is not mandatory but optional to apply for the ethical review and approval at Ritsumeikan University (http:/ / www.ritsumei.ac.jp/research/approach/ethics/mankind/).

Informed Consent Statement: Informed consent was obtained from all subjects involved in the study. Data Availability Statement: The data presented in this study are available in the Supplementary Material.

Conflicts of Interest: The authors declare no conflict of interest. 


\section{References}

1. Steffen, W.; Crutzen, J.; McNeill, J.R. The Anthropocene: Are humans now overwhelming the great forces of Nature? Ambio 2007, 36, 614-621. [CrossRef]

2. Steffen, W.; Sanderson, R.A.; Tyson, P.D.; Jäger, J.; Matson, P.A.; Moore III, B.; Oldfield, F.; Richardson, K.; Schellnhuber, H.-J.; Turner, B.L.; et al. Global Change and the Earth System: A Planet under Pressure; Springer: New York, NY, USA, 2004.

3. Clark, G. Evolution of the global sustainable consumption and production policy and the United Nations Environment Programme's (UNEP) supporting activities. J. Clean. Prod. 2007, 15, 492-498. [CrossRef]

4. Rockstrom, J.; Steffen, W.; Noone, K.; Persson, A.; Chapin, F.S.; Lambin, E.F.; Lenton, T.M.; Scheffer, M.; Folke, C.; Schellnhuber, H.J.; et al. A safe operating space for humanity. Nature 2009, 461, 472-475. [CrossRef]

5. UNEP. Sustainable Consumption and Production: A Handbook for Policymakers (Global Edition); UN: Nairobi, Kenya, 2016; ISBN 9210601580.

6. Moisander, J. Motivational complexity of green consumerism. Int. J. Consum. Stud. 2007, 31, 404-409. [CrossRef]

7. Fackle-Fornius, E.; Wänström, L.A. Minimax D-optimal designs of contingent valuation experiments: Willingness to pay for environmentally friendly clothes. J. Appl. Stat. 2014, 41, 895-908. [CrossRef]

8. Peattie, K. Environmental Marketing Management: Meeting the Green Challenge; Financial Times Management: London, UK, 1995; ISBN 0273602799.

9. Chen, Y.-S.; Chang, C.-H. The determinants of green product development performance: Green dynamic capabilities, green transformational leadership, and green creativity. J. Bus. Ethics 2013, 116, 107-119. [CrossRef]

10. Joshi, Y.; Rahman, Z. Factors Affecting Green Purchase Behaviour and Future Research Directions. Int. Strateg. Manag. Rev. 2015, 3, 128-143. [CrossRef]

11. Magnusson, M.K.; Arvola, A.; Hursti, U.K.; Åberg, L.; Sjödén, P. Attitudes towards organic foods among Swedish consumers. Br. Food J. 2001, 103, 209-227. [CrossRef]

12. Goucher-Lambert, K.; Cagan, J. The Impact of Sustainability on Consumer Preference Judgments of Product Attributes. J. Mech Des. 2015, 137, 081401. [CrossRef]

13. Blarney, R.; Bennett, J. Yea-saying and validation of a choice model of green product choice. In The Choice Modelling Approach to Environmental Valuation; Edward Elgar Publishing: Cheltenham, UK, 2001; pp. 178-201.

14. Schuitema, G.; De Groot, J.I.M. Green consumerism: The influence of product attributes and values on purchasing intentions. J. Consum. Behav. 2015, 14, 57-69. [CrossRef]

15. Bamberg, S. How does environmental concern influence specific environmentally related behaviors? A new answer to an old question. J. Environ. Psychol. 2003, 23, 21-32. [CrossRef]

16. Barr, S. Environmental action in the home: Investigating the 'value-action' gap. Geography 2006, 91, 43-54. [CrossRef]

17. Rokka, J.; Uusitalo, L. Preference for green packaging in consumer product choices-Do consumers care? Int. J. Consum. Stud. 2008, 32, 516-525. [CrossRef]

18. Olson, E.L. It's not easy being green: The effects of attribute tradeoffs on green product preference and choice. J. Acad. Mark. Sci. 2013, 41, 171-184. [CrossRef]

19. Hughner, R.S.; McDonagh, P.; Prothero, A.; Shultz, C.J.; Stanton, J. Who are organic food consumers? A compilation and review of why people purchase organic food. J. Consum. Behav. An Int. Res. Rev. 2007, 6, 94-110. [CrossRef]

20. Follows, S.B.; Jobber, D. Environmentally responsible purchase behaviour: A test of a consumer model. Eur. J. Mark. 2000, 34, 723-746. [CrossRef]

21. Peattie, K. Trappings versus substance in the greening of marketing planning. J. Strateg. Mark. 1999, 7, 131-148. [CrossRef]

22. Peattie, K. Green consumption: Behavior and norms. Annu. Rev. Environ. Resour. 2010, 35, 195-228. [CrossRef]

23. Nguyen, M.T.T.; Nguyen, L.H.; Nguyen, H.V. Materialistic values and green apparel purchase intention among young Vietnamese consumers. Young Consum. 2019, 20, 246-263. [CrossRef]

24. Yadav, R.; Pathak, G.S. Young consumers' intention towards buying green products in a developing nation: Extending the theory of planned behavior. J. Clean. Prod. 2016, 135, 732-739. [CrossRef]

25. Dardanoni, V.; Guerriero, C. Young people's willingness to pay for environmental protection. Ecol. Econ. 2021, 179, 106853. [CrossRef]

26. Sesini, G.; Castiglioni, C.; Lozza, E. New trends and patterns in sustainable consumption: A systematic review and research agenda. Sustainability 2020, 12, 5935. [CrossRef]

27. Gesiot, M. Explaining Adoption and Market Success of “Green Products"-A Conjoint Analysis Experiment on German Students' Preferences on Eco-Labels. Master's Thesis, Técnico Lisboa, Lisbon, Portugal, 2014.

28. Miller, S.; Tait, P.; Saunders, C.; Dalziel, P.; Rutherford, P.; Abell, W. Estimation of consumer willingness-to-pay for social responsibility in fruit and vegetable products: A cross-country comparison using a choice experiment. J. Consum. Behav. 2017, 16, e13-e25. [CrossRef]

29. Liobikiene, G.; Mandravickaite, J.; Bernatoniene, J. Theory of planned behavior approach to understand the green purchasing behavior in the EU: A cross-cultural study. Ecol. Econ. 2016, 125, 38-46. [CrossRef]

30. Lee, Y.-K. The relationship between green country image, green trust, and purchase intention of Korean products: Focusing on Vietnamese Gen Z consumers. Sustainability 2020, 12, 5098. [CrossRef] 
31. McDonald, S.; Oates, C.; Thyne, M.; Alevizou, P.; McMorland, L.A. Comparing sustainable consumption patterns across product sectors. Int. J. Consum. Stud. 2009, 33, 137-145. [CrossRef]

32. Witek, L.; Kuźniar, W. Green purchase behavior: The effectiveness of sociodemographic variables for explaining green purchases in emerging market. Sustainability 2021, 13, 209. [CrossRef]

33. Young, W.; Hwang, K.; McDonald, S.; Oates, C.J. Sustainable consumption: Green consumer behaviour when purchasing products. Sustain. Dev. 2010, 18, 20-31. [CrossRef]

34. Čapienè, A.; Rūtelionè, A.; Tvaronavičienè, M. Pro-Environmental and Pro-Social Engagement in Sustainable Consumption: Exploratory Study. Sustainability 2021, 13, 1601. [CrossRef]

35. White, K.; Habib, R.; Hardisty, D.J. How to SHIFT consumer behaviors to be more sustainable: A literature review and guiding framework. J. Mark. 2019, 83, 22-49. [CrossRef]

36. Albloushy, H.; Hiller Connell, K.Y. Purchasing environmentally sustainable apparel: The attitudes and intentions of female Kuwaiti consumers. Int. J. Consum. Stud. 2019, 43, 390-401. [CrossRef]

37. Kozar, J.M.; Connell, K.Y.H. Socially and environmentally responsible apparel consumption: Knowledge, attitudes, and behaviors. Soc. Responsib. J. 2013, 9, 316-325. [CrossRef]

38. Hustvedt, G.; Dickson, M.A. Consumer likelihood of purchasing organic cotton apparel: Influence of attitudes and selfidentity. J. Fash. Mark. Manag. 2009, 13, 49-65. [CrossRef]

39. Matthews, D.; Rothenberg, L. An assessment of organic apparel, environmental beliefs and consumer preferences via fashion innovativeness. Int. J. Consum. Stud. 2017, 41, 526-533. [CrossRef]

40. Rothenberg, L.; Matthews, D. Consumer decision making when purchasing eco-friendly apparel. Int. J. Retail Distrib. Manag. 2017, 45, 404-418. [CrossRef]

41. Tait, P.; Saunders, C.; Dalziel, P.; Rutherford, P.; Driver, T.; Guenther, M. Estimating wine consumer preferences for sustainability attributes: A discrete choice experiment of Californian Sauvignon blanc purchasers. J. Clean. Prod. 2019, 233, 412-420. [CrossRef]

42. De Medeiros, J.F.; Ribeiro, J.L.D.; Cortimiglia, M.N. Influence of perceived value on purchasing decisions of green products in Brazil. J. Clean. Prod. 2016, 110, 158-169. [CrossRef]

43. Lin, P.C.; Huang, Y.H. The influence factors on choice behavior regarding green products based on the theory of consumption values. J. Clean. Prod. 2012, 22, 11-18. [CrossRef]

44. Michaud, C.; Llerena, D. Green consumer behaviour: An experimental analysis of willingness to pay for remanufactured products. Bus. Strateg. Environ. 2011, 20, 408-420. [CrossRef]

45. Yadav, R.; Pathak, G.S. Determinants of consumers' green purchase behavior in a developing nation: Applying and extending the theory of planned behavior. Ecol. Econ. 2017, 134, 114-122. [CrossRef]

46. Taufique, K.M.R.; Vaithianathan, S. A fresh look at understanding Green consumer behavior among young urban Indian consumers through the lens of Theory of Planned Behavior. J. Clean. Prod. 2018, 183, 46-55. [CrossRef]

47. Sharma, A.; Foropon, C. Green product attributes and green purchase behavior: A theory of planned behavior perspective with implications for circular economy. Manag. Decis. 2019, 57, 1018-1042. [CrossRef]

48. Chen, Y.S.; Chang, C.H. Enhance green purchase intentions: The roles of green perceived value, green perceived risk, and green trust. Manag. Decis. 2012, 50, 502-520. [CrossRef]

49. Cheung, M.F.Y.; To, W.M. An extended model of value-attitude-behavior to explain Chinese consumers' green purchase behavior. J. Retail. Consum. Serv. 2019, 50, 145-153. [CrossRef]

50. Güngör-Demirci, G.; Lee, J.; Mirzaei, M.; Younos, T. How do people make a decision on bottled or tap water? Preference elicitation with nonparametric bootstrap simulations. Water Environ. J. 2016, 30, 243-252. [CrossRef]

51. Michaud, C.; Llerena, D.; Joly, I. Willingness to pay for environmental attributes of non-food agricultural products: A real choice experiment. Eur. Rev. Agric. Econ. 2013, 40, 313-329. [CrossRef]

52. Ngô, D.; Phạm, N. Thúc đẩy tiêu dùng xanh của các hộ gia đình Việt Nam hiện nay. Available online: http://tapchitaichinh.vn/ nghien-cuu-trao-doi/thuc-day-tieu-dung-xanh-cua-cac-ho-gia-dinh-viet-nam-hien-nay-302162.html (accessed on 5 May 2021).

53. De Koning, J.I.J.C.; Crul, M.R.M.; Wever, R.; Brezet, J.C. Sustainable consumption in Vietnam: An explorative study among the urban middle class. Int. J. Consum. Stud. 2015, 39, 608-618. [CrossRef]

54. Nguyen, T.N.; Lobo, A.; Nguyen, B.K. Young consumers' green purchase behaviour in an emerging market. J. Strateg. Mark. 2018, 26, 583-600. [CrossRef]

55. Japan for Sustainability Green Purchasing and Green Procurement in Motion. Available online: https://www.japanfs.org/en/ news/archives/news_id027751.html\#: \{\}:text=Inrecentyears\%2Cgreenprocurement,\%2CcompaniesandNGOs\%2Fcitizens (accessed on 5 May 2021).

56. Holmes, T.P.; Adamowicz, W.L.; Carlsson, F. Choice experiments. In A Primer on Nonmarket Valuation; Springer, Ed.; Springer: Dordrecht, The Netherlands, 2017; pp. 133-186.

57. Alriksson, S.; Öberg, T. Conjoint analysis for environmental evaluation: A review of methods and applications. Environ. Sci. Pollut. Res. 2008, 15, 244-257. [CrossRef] [PubMed]

58. Louviere, J.J.; Hensher, D.A.; Swait, J.D. Stated Choice Methods: Analysis and Applications; Cambridge University Press: Cambridge, UK, 2000; ISBN 0521788307.

59. McFadden, D. Conditional logit analysis of qualitative choice behavior. In Frontiers in Econometrics; Zarembka, P., Ed.; Academic Press: New York, NY, USA, 1973; pp. 105-142. 
60. Aizaki, H.; Nakatani, T.; Sato, K. Stated Preference Methods Using R; CRC Press: Boca Raton, USA, 2015.

61. Steffen, W.; Richardson, K.; Rockström, J.; Cornell, S.E.; Fetzer, I.; Bennett, E.M.; Biggs, R.; Carpenter, S.R.; de Vries, W.; de Wit, C.A.; et al. Planetary boundaries: Guiding human development on a changing planet. Science 2015, 347, 1259855. [CrossRef]

62. Sustain Your Style What's Wrong with the Fashion Industry? Available online: https://www.sustainyourstyle.org/en/whatswrong-with-the-fashion-industry?gclid=CjwKCAiAnIT9BRAmEiwANaoE1Z81Uerryi5BczxAnurI_n6KXet5CAWhnP8eYnov_ N5LW5i0ZcBRLRoCrikQAvD_BwE (accessed on 5 May 2021).

63. Sowmiya 7 Pros and Cons of Sustainable Fashion. Available online: https://thefashionmessanger.com/pros-and-cons-ofsustainable-fashion/ (accessed on 5 May 2021).

64. Boyd, J.; Krupnick, A. The definition and choice of environmental commodities for nonmarket valuation. SSRN Electron. J. 2009. [CrossRef]

65. Blamey, R.K.; Bennett, J.W.; Louviere, J.J.; Morrison, M.D.; Rolfe, J.C. Attribute causality in environmental choice modelling. Environ. Resour. Econ. 2002, 23, 167-186. [CrossRef]

66. Ginsberg, J.M.; Bloom, P.N. Choosing the right green marketing strategy. MIT Sloan Manag. Rev. 2004, 46, 79-84.

67. Tanner, C.; Wölfing Kast, S. Promoting sustainable consumption: Determinants of green purchases by Swiss consumers. Psychol. Mark. 2003, 20, 883-902. [CrossRef]

68. BIO Intelligence Service. Study on Different Options for Communicating Environmental Information for Products; European Commission: Brussels, Belgium, 2012.

69. Johnson, F.R.; Lancsar, E.; Marshall, D.; Kilambi, V.; Mühlbacher, A.; Regier, D.A.; Bresnahan, B.W.; Kanninen, B.; Bridges, J.F.P. Constructing experimental designs for discrete-choice experiments: Report of the ISPOR conjoint analysis experimental design good research practices task force. Value Health 2013, 16, 3-13. [CrossRef] [PubMed]

70. Boyle, K.J.; Brown, T.C.; Champ, P.A. A Primer on Nonmarket Valuation; Springer: Dordrecht, The Netherlands, 2017; ISBN 9400771045.

71. Chan, R.Y.K. Determinants of Chinese consumers' green purchase behavior. Psychol. Mark. 2001, 18, 389-413. [CrossRef]

72. Ogiemwonyi, O.; Harun, A.B.; Alam, M.N.; Karim, A.M.; Tabash, M.I.; Hossain, M.I.; Aziz, S.; Abbasi, B.A.; Ojuolape, M.A. Green product as a means of expressing green behaviour: A cross-cultural empirical evidence from Malaysia and Nigeria. Environ. Technol. Innov. 2020, 20, 101055. [CrossRef]

73. Haws, K.L.; Winterich, K.P.; Naylor, R.W. Seeing the world through GREEN-tinted glasses: Green consumption values and responses to environmentally friendly products. J. Consum. Psychol. 2014, 24, 336-354. [CrossRef]

74. Statistics Bureau of Japan Current Population Estimates as of. 2019. Available online: https://www.stat.go.jp/english/data/ jinsui/2019np/index.html (accessed on 5 May 2021).

75. General Statistics Office of Vietnam Population Change and Family Planning Survey 1/4 Period 2007-2017. Available online: https: / / www.gso.gov.vn/en/px-web/?pxid=E0209\&theme=PopulationandEmployment (accessed on 5 May 2021).

76. Japan Student Services Organization. Survey on Students' Life, Year 2018; Japan Student Services Organization: Tokyo, Japan, 2020.

77. Lance, C.E.; Butts, M.M.; Michels, L.C. The sources of four commonly reported cutoff criteria: What did they really say? Organ. Res. Methods 2006, 9, 202-220. [CrossRef]

78. Churchill, S.A.; Inekwe, J.; Ivanovski, K.; Smyth, R. The Environmental Kuznets Curve in the OECD: 1870-2014. Energy Econ. 2018, 75, 389-399. [CrossRef]

79. Haller, K.; Lee, J.; Cheung, J. Meet the 2020 Consumers Driving Change. Why Brands must Deliver on Omnipresence, Agility, and Sustainability; IBM: Armonk, NY, USA, 2020.

80. Mitra, A.; Boussie, A.; Ortiz, A.; Longworth, B.S.; Wijaya, D.; Klerk, E.; Wong, J.; Natzkoff, J.; Fong, K.; Recchia, M.; et al. Emerging Consumer Survey 2021: A world beyond the pandemic; Credit Suisse: Zurich, Switzerland, 2021.

81. World Health Organization (WHO). Air Pollution Levels Rising in Many of the World's Poorest Cities. Available online: https:/ / www.who.int/news/item/12-05-2016-air-pollution-levels-rising-in-many-of-the-world-s-poorest-cities (accessed on 5 May 2021).

82. Health and Environment Linkages Initiative-HELI Environment and Health in Developing Countries. Available online: https:/ / www.who.int/heli/risks/ehindevcoun/en/ (accessed on 5 May 2021).

83. Thong, N.T.; Nguyen, D.H.; Bich, P.T.N.; Huong, L.T.M. Sustainable consumption and production in Vietnam. In Sustainable Asia Supporting the Transition to Sustainable Consumption and Production in Asian Developing Countries; World Scientific Publishing Co.: Toh Tuck Link, Singapore, 2017; pp. 327-356.

84. Yagi, M.; Kokubu, K. A framework of sustainable consumption and production from the production perspective: Application to Thailand and Vietnam. J. Clean. Prod. 2020, 276, 124160. [CrossRef]

85. Yale Center for Environmental Law \& Policy Environmental Performance Index. Available online: https://epi.yale.edu/epiresults/2020/component/epi (accessed on 5 May 2021).

86. Luu, Q. $80 \%$ người tiêu dùng sẵn sàng chi nhiều hơn cho sản phẩm xanh và sạch. Available online: https://moit.gov.vn/tin-tuc/ hoat-dong/80-nguoi-tieu-dung-san-sang-chi-nhieu-hon-cho-san-pham-xanh-2.html (accessed on 5 May 2021).

87. Laroche, M.; Bergeron, J.; Barbaro-Forleo, G. Targeting consumers who are willing to pay more for environmentally friendly products. J. Consum. Mark. 2001, 18, 503-520. [CrossRef]

88. Fisher, C.; Bashyal, S.; Bachman, B. Demographic impacts on environmentally friendly purchase behaviors. J. Targeting, Meas. Anal. Mark. 2012, 20, 172-184. [CrossRef] 
89. Mehmet, A.; Gül, B. Demographic characteristics of consumer buying behavior effects of environmentally friendly products and an application in Gaziantep. Bus. Manag. Rev. 2014, 5, 72.

90. Hunter, L.M.; Hatch, A.; Johnson, A. Cross-national gender variation in environmental behaviors. Soc. Sci. Q. 2004, 85, 677-694. [CrossRef]

91. Brough, A.R.; Wilkie, J.E.B.; Isaac, M.S. Is Eco-Friendly Unmanly? The Green-Feminine Stereotype and Its Effect on Sustainable Consumption. J. Consum. Res. 2016, 43, 567-582. [CrossRef]

92. Nishi, H.; Yanagizawa, S. Learning Through part-time job experience for university students: The effect of the goal of part-time jobs and the consciousness of activities. Bull. Nakamura Gakuen Univ. Nakamura Gakuen Jr Univ. 2010, 42, $285-292$.

93. WBCSD. Sustainable Consumption Fact. and Trends From a Business Perspective; WBCSD: Geneva, Switzerland, 2008.

94. Varela-Candamio, L.; Novo-Corti, I.; García-Álvarez, M.T. The importance of environmental education in the determinants of green behavior: A meta-analysis approach. J. Clean. Prod. 2018, 170, 1565-1578. [CrossRef]

95. Latinopoulos, D.; Mentis, C.; Bithas, K. The impact of a public information campaign on preferences for marine environmental protection. The case of plastic waste. Mar. Pollut. Bull. 2018, 131, 151-162. [CrossRef]

96. Toda, M. Shoppers Decline to Pay for Plastic Bags in Win for Plan to Cut Waste. Available online: https://www.asahi.com/ajw/ articles /14007440 (accessed on 5 May 2021).

97. Truelove, H.B.; Carrico, A.R.; Weber, E.U.; Raimi, K.T.; Vandenbergh, M.P. Positive and negative spillover of pro-environmental behavior: An integrative review and theoretical framework. Glob. Environ. Chang. 2014, 29, 127-138. [CrossRef]

98. Sterner, T.; Barbier, E.B.; Bateman, I.; van den Bijgaart, I.; Crépin, A.S.; Edenhofer, O.; Fischer, C.; Habla, W.; Hassler, J.; Johansson-Stenman, O.; et al. Policy design for the Anthropocene. Nat. Sustain. 2019, 2, 14-21. [CrossRef]

99. Ho, T.T. Impact of Green Consumption Trends on Vietnamese Businesses; Sustainable Production and Consumption Office. Available online: https: / scp.gov.vn/tin-tuc/t10537/tac-dong-cua-xu-huong-tieu-dung-xanh-den-doanh-nghiep-viet-nam. html (accessed on 5 May 2021).

100. Nguyen, T.P.; Dekhili, S. Sustainable development in Vietnam: An examination of consumers' perceptions of green products. Bus. Strateg. Dev. 2019, 2, 127-136. [CrossRef]

101. Huong, N.T. Project "Stimulating the Demand and Supply of Sustainable Products Through Sustainable Public Procurement and Ecolabelling" (Sppel); UNEP: Nairobi, Kenya, 2016.

102. Stucki, T.; Woerter, M.; Arvanitis, S.; Peneder, M.; Rammer, C. How different policy instruments affect green product innovation: A differentiated perspective. Energy Policy 2018, 114, 245-261. [CrossRef]

103. Terlau, W.; Hirsch, D. Sustainable consumption and the attitude-behaviour-gap phenomenon-causes and measurements towards a sustainable development. Int. J. Food Syst. Dyn. 2015, 6, 159-174.

104. Jaiswal, D.; Singh, B. Toward sustainable consumption: Investigating the determinants of green buying behaviour of Indian consumers. Bus. Strateg. Dev. 2018, 1, 64-73. [CrossRef]

105. Hohn, S.; Acevedo-Trejos, E.; Abrams, J.F.; Fulgencio de Moura, J.; Spranz, R.; Merico, A. The long-term legacy of plastic mass production. Sci. Total Environ. 2020, 746, 141115. [CrossRef]

106. Lau, W.W.Y.; Shiran, Y.; Bailey, R.M.; Cook, E.; Stuchtey, M.R.; Koskella, J.; Velis, C.A.; Godfrey, L.; Boucher, J.; Murphy, M.B.; et al. Evaluating scenarios toward zero plastic pollution. Science 2020, 369, 1455-1461. [CrossRef]

107. David, J.; Blonner, M.; Forbes, M.K.; Norberg, M.M. Motives for acquiring and saving and their relationship with object attachment. Curr. Opin. Psychol. 2021, 39, 1-5. [CrossRef]

108. Schifferstein, H.N.J.; Mugge, R.; Hekkert, P. Designing consumer-product attachment. In Design and Emotion; Taylor \& Francis: London, UK, 2004; pp. 327-331. 